Article

\title{
Development of a Watershed-Scale Long-Term Hydrologic Impact Assessment Model with the Asymptotic Curve Number Regression Equation
}

\author{
Jichul Ryu ${ }^{1}$, Won Seok Jang ${ }^{2}$, Jonggun Kim ${ }^{3}$, Joong Dae Choi ${ }^{4}$, Bernard A. Engel ${ }^{2}$, Jae E. Yang ${ }^{5}$ \\ and Kyoung Jae Lim ${ }^{4, *}$ \\ 1 Water Pollution Load Management Research Division, National Institute of Environmental Research, \\ Seogu, Incheon 22689, Korea; ryujichul84@gmail.com \\ 2 Department of Agricultural \& Biological Engineering, Purdue University, \\ West Lafayette, IN 47907-2093, USA; Jang55@purdue.edu (W.S.J.); engelb@purdue.edu (B.A.E.) \\ 3 Department of Biological and Agricultural Engineering, Texas A\&M University, \\ College Station, TX 77843, USA; jgkim23@tamu.edu \\ 4 Department of Regional Infrastructure Engineering, Kangwon National University, \\ Chuncheon, Gangwon 24341, Korea; jdchoi@kangwon.ac.kr \\ 5 Department of Biological Environment, Kangwon National University, Chuncheon, Gangwon 24341, Korea; \\ yangjay@kangwon.ac.kr \\ * Correspondence: kjlim@kangwon.ac.kr; Tel.: +82-33-229-9069; Fax: +82-33-862-3442
}

Academic Editor: Miklas Scholz

Received: 29 January 2016; Accepted: 8 April 2016; Published: 16 April 2016

\begin{abstract}
In this study, 52 asymptotic Curve Number $(\mathrm{CN})$ regression equations were developed for combinations of representative land covers and hydrologic soil groups. In addition, to overcome the limitations of the original Long-term Hydrologic Impact Assessment (L-THIA) model when it is applied to larger watersheds, a watershed-scale L-THIA Asymptotic CN (ACN) regression equation model (watershed-scale L-THIA ACN model) was developed by integrating the asymptotic CN regressions and various modules for direct runoff/baseflow/channel routing. The watershed-scale L-THIA ACN model was applied to four watersheds in South Korea to evaluate the accuracy of its streamflow prediction. The coefficient of determination $\left(R^{2}\right)$ and Nash-Sutcliffe Efficiency (NSE) values for observed versus simulated streamflows over intervals of eight days were greater than 0.6 for all four of the watersheds. The watershed-scale L-THIA ACN model, including the asymptotic $\mathrm{CN}$ regression equation method, can simulate long-term streamflow sufficiently well with the ten parameters that have been added for the characterization of streamflow.
\end{abstract}

Keywords: asymptotic; CN; L-THIA; regression; streamflow; watershed-scale model

\section{Introduction}

In recent years, environmental disasters, such as droughts and floods, caused by climate changes have increased in occurrence, and various approaches to finding solutions for these issues have been suggested and investigated [1-4]. Estimation of runoff in watersheds is very important to preventing droughts and floods, preserving the ecological integrity of aquatic systems and managing water quality [5-7]. There are two ways to estimate the runoff in a watershed: monitoring of streamflow and use of rainfall-runoff models.

Monitoring of streamflow is more accurate than the use of computer models in estimating runoff in a watershed. However, it can be difficult to measure streamflow in all of the subbasins in a watershed without appropriate manpower and financial resources. In addition, it can be difficult to collect streamflow data during flooding and typhoon seasons [8]. Furthermore, for sustainable 
watershed management, prediction of future streamflow changes with climate/land use changes should be considered. For these reasons, watershed-scale continuous rainfall-runoff models have been widely used for management of hydrology and environment plans because these computer models can be used to estimate the long-term streamflow at gauged/ungauged subbasins efficiently [9-13].

There are many computer rainfall-runoff models available for use in estimating runoff, including SWAT (Soil and Water Assessment Tool) [14], L-THIA (Long-Term Hydrologic Impact Assessment) [15-17], SWMM (Storm Water Management Tool) [18,19] and STEPL (Spreadsheet Tool for Estimating Pollutant Load) [20,21], among others. Most of these models calculate direct runoff using the Curve Number (CN) method proposed by the Natural Resources Conservation Service (NRCS-CN) [22].

The L-THIA model is simpler than some other models, such as SWAT and HSPF. In addition, the L-THIA model can calculate direct runoff and pollutant loads with a limited number of input parameters, such as rainfall data, land cover and hydrologic soil group data [15,17]. The L-THIA model has been developed in web and ArcGIS versions [23-27]. It has been used in the calculation of runoff and pollutant loads in many studies. Recently, a version of the L-THIA model with low-impact development (LID) capability was developed and has been used for efficient watershed management purposes, such as the determination of Total Maximum Daily Loads (TMDLs), in the USA [28].

However, the NRCS-CN method used in the L-THIA model cannot be used to calculate direct runoff accurately during low-flow seasons because the static CN value considered in the NRCS-CN method does not explain the relationship between rainfall and asymptotic CN, especially for lower-rainfall-CN datasets [29].

According to the relationships between rainfall and $\mathrm{CN}$ suggested by numerous rainfall-runoff datasets [30], the $\mathrm{CN}$ decreases as the rainfall increases and converges to an asymptotic $\mathrm{CN}$. However, some previous studies on the asymptotic CN method [30-36] have been limited in that they have considered only ungaged watersheds, whereas other studies have considered only gaged watersheds and have employed regression equations from datasets for gaged watersheds in direct runoff estimation.

To overcome this limitation, thirteen Land Cover-based Asymptotic CN (ACN) Regression Equations (LC-ACN-REs) were proposed for the estimation of runoff in ungaged watersheds, and these equations were applied to TMDL watersheds in South Korea [29]. The results of comparisons between observed and estimated runoff indicated that LC-ACN-REs can simulate direct runoff very well in comparison to the NRCS-CN method. Although LC-ACN-REs have been proven to be efficient tools for accurate estimation of direct runoff, they are still limited in that the effects of hydrologic soil groups on direct runoff estimation cannot be simulated.

The L-THIA model has been used for runoff estimation on the watershed scale $[16,25,26,37]$. However, the L-THIA model is not applicable to larger watersheds, because it does not consider the lag time for direct runoff to reach streams, which could be more than one day, meaning that only a fraction of the direct runoff will flow into streams on the day of simulation [38]. In addition, the current L-THIA model does not simulate baseflow and channel routing within watershed structures and does not consider point source discharge.

The objectives of this study were as follows: (1) to extend the available LC-ACN-REs to consider hydrologic soil groups $(\mathrm{A}, \mathrm{B}, \mathrm{C}, \mathrm{D})$, as described in the NEH-4 CN (National Engineering Handbook Chapter 4) table [22]; (2) to develop a watershed-scale model of the Long-term Hydrologic Impact Assessment with the extended LC-ACN-REs (the watershed-scale L-THIA ACN model) by adding modules for direct runoff, baseflow and channel routing; and (3) to evaluate this LC-ACN-RE-enhanced watershed-scale L-THIA ACN model with soil component, lag time, baseflow and channel routing capabilities. 


\section{Materials and Methods}

\subsection{LC-ACN-RE Approach to Considering Hydrologic Soil Groups}

In the project "Long-term monitoring of Nonpoint Source (NPS) pollution" funded by the Ministry of Environment (MOE) of South Korea, runoff and water quality samples were collected for each representative land cover type rather than for specific Hydrologic Soil Groups (HSGs) or other soil infiltration properties. Thus, the LC-ACN-REs developed by [29] were classified as being applicable by land cover type; the effects of soil infiltration properties on direct runoff estimation cannot be analyzed with LC-ANC-RE approaches.

To overcome this limitation of the LC-CAN-REs [29], rainfall and direct runoff data from the "Long-term monitoring of Nonpoint-Source (NPS) pollution" project were analyzed to obtain the $\mathrm{CN}$ value for each combination of rainfall and direct runoff using Equation (1), which was proposed by Hawkins [30]. HSG information for the monitoring site was then compiled for use in estimating $\mathrm{CN}$ values for other HSGs. The CN values for other HSGs were estimated by multiplying the $\mathrm{CN}$ values obtained using Equation (1) by the ratios of the CN values for other HSGs in the NEH-4 CN table (Table 1). After obtaining the CN values for 13 land cover types and four HSG combinations, 52 asymptotic regression equations, such as the following, were obtained from regression analysis, as illustrated in Figure 1 (Equation (2) [30]).

$$
C N=25400 / 254+5\left[P+2 Q-\sqrt{4 Q^{2}+5 P Q}\right]
$$

where $Q$ is the direct runoff $(\mathrm{mm})$ and $P$ is the rainfall $(\mathrm{mm})$.

$$
C N(P)=C N_{\infty}+\left(100-C N_{\infty}\right) \exp (-k P)
$$

where $C N_{\infty}$ is the asymptotic $C N$ value, $P$ is the rainfall $(\mathrm{mm})$ and $k$ is a fitting constant.

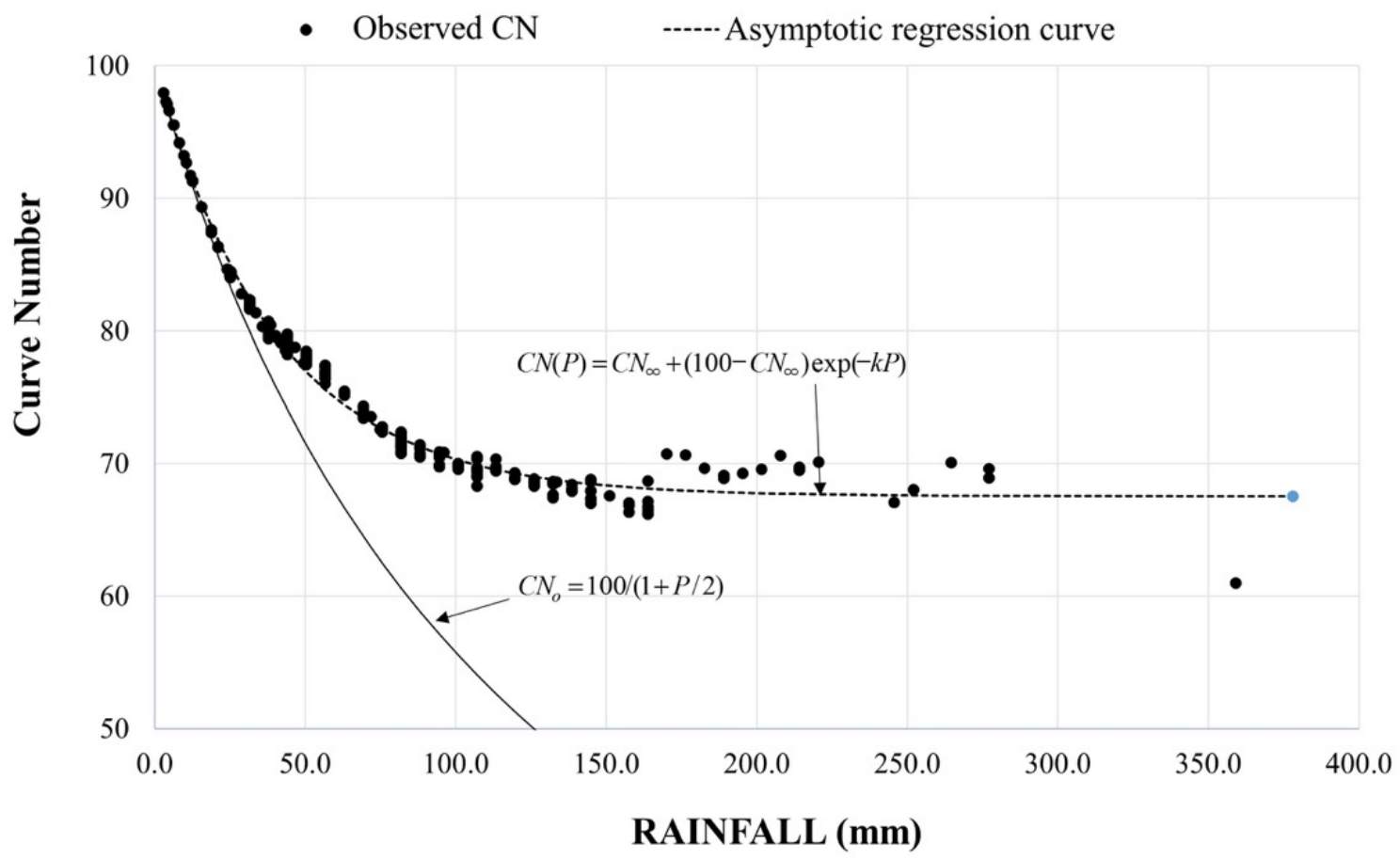

Figure 1. Asymptotic $\mathrm{CN}$ regressions obtained in the study by Hawkins [30]. $\mathrm{CN}(\mathrm{P})$ is the Curve Number as a function of rainfall, and $C N_{0}=100 /(1+P / 2)$ defines a threshold below which no runoff occurs until the rainfall $\mathrm{P}$ in mm exceeds an initial abstraction of $20 \%$ of the maximum potential retention. 
Table 1. CN values for thirteen land cover types and Hydrologic Soil Groups (HSGs) from Land Cover-based Asymptotic CN Regression Equations (LC-ACN-REs). NEH-4, National Engineering Handbook Chapter 4.

\begin{tabular}{ccccc}
\hline Name of the Land Cover in & \multicolumn{3}{c}{ CN Value in NEH-4 CN Table for Individual Soil Type [22] } \\
\cline { 2 - 5 } LC-ACN-RE Approach & A & B & C & D \\
\hline Residential area & 77 & 85 & 90 & 92 \\
Manufacturing area & 81 & 88 & 91 & 93 \\
Regional public facility area & 89 & 92 & 94 & 95 \\
Recreational facility area & 89 & 92 & 94 & 95 \\
Road & 98 & 98 & 98 & 98 \\
Commercial area & 89 & 92 & 94 & 95 \\
Upland & 62 & 71 & 78 & 81 \\
Orchard & 62 & 71 & 78 & 81 \\
Greenhouse & 62 & 71 & 78 & 81 \\
Paddy & 62 & 71 & 78 & 81 \\
Pasture & 30 & 58 & 71 & 78 \\
Forest & 45 & 66 & 77 & 93 \\
Bare land & 77 & 86 & 91 & \\
\hline
\end{tabular}

\subsection{Development of the Watershed-Scale L-THIA ACN Model}

The watershed-scale L-THIA ACN model developed in this study consists of three modules, for direct runoff, baseflow (with extended LC-ACN-REs developed as described in Section 2.1) and channel routing capabilities (Figure 2). The model requires daily rainfall, point source data and hydrological response unit (HRU) mapping created by combining a subbasin map, a soil map and a land use map.

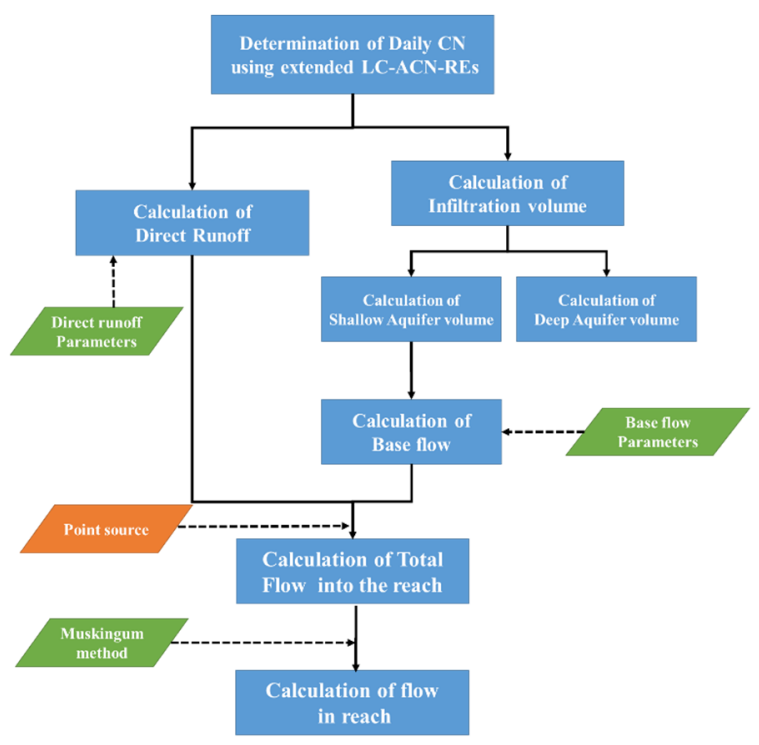

Figure 2. Flow diagram for the development of watershed-scale L-THIA ACN model.

\subsubsection{Development of the Direct Runoff Estimation Module}

As explained above, the 52 asymptotic regression equations (Equation (2)) were obtained for 13 land cover types and four HSGs. Using these equations, the CN values for a given set of daily rainfall data were computed for all land cover and HSG combinations for each watershed studied.

According to various studies on the NRCS-CN method, $\mathrm{CN}$ values can be adjusted based on the slope in a watershed [39], as well as for various local conditions that affect rainfall-runoff. Thus, an 
adjustment coefficient was added to explain the effect of the slope on the $\mathrm{CN}$ values (Equation (3)). In this study, the limits of the range for the adjustment coefficient for $\mathrm{CN}$ were set to -0.1 and +0.1 $(-10 \%$ and $+10 \%)$.

$$
\text { Adj_CN } C N_{H R U}=C N_{H R U, A C N} \times A d j \_C N
$$

where $C N_{H R U}$ is the adjusted $\mathrm{CN}$ value for $\mathrm{HRU}, A d j_{-} C N_{H R U}, A C N$ is the $\mathrm{CN}$ value determined from the extended LC-ACN-REs and Adj_CN is the adjusted coefficient for CN.

After adjustment of the $\mathrm{CN}$ values, the direct runoff of each HRU was estimated (Equation (4)).

$$
Q_{D R, H R U}^{1}=\frac{(P-0.2 S)^{2}}{(P+0.8 S)}, P \geqslant 0.2 S, S=\frac{25400}{A d j_{-} C N_{H R U}}-254
$$

where $Q^{1} D R, H R U$ is the amount of direct runoff generated by an HRU for each day (mm), $P$ is the rainfall $(\mathrm{mm}), S$ is the potential maximum retention $(\mathrm{mm})$ and $A d j \_C N_{H R U, A C N}$ is the adjusted coefficient for $\mathrm{CN}$.

In a large-scale watershed, the amount of direct runoff that occurs on a day can be lagged, and only a portion of the direct runoff will flow into a stream on a day. Thus, in this study, the direct runoff delay process was addressed in the module in the form of an exponential function of the time of concentration (TC) and the lag coefficient $\left(D R_{\text {lag }}\right)$, as proposed in the SWAT model (Equation (5)) [38].

Once the direct runoff of each HRU is calculated using Equation (4), the amount of direct runoff flowing into the stream can be calculated using Equation (5).

$$
Q_{D R, H R U}=\left(Q_{D R, H R U}^{1}+Q_{\text {stor }, i-1}\right) \times\left(1-\exp \left[\frac{-D R_{\text {lag }}}{T C}\right]\right)
$$

where $Q_{D R, H R U}$ is the amount of direct runoff discharged to the main channel on a given day (mm), $Q^{1}{ }_{D R, H R U}$ is amount of direct runoff generated by the HRU on a given day (mm), $Q_{\text {stor }}$ is the direct runoff lagged from the previous day, $D R_{\operatorname{lag}}$ is the direct runoff lag coefficient and $T C$ is the time of concentration (h).

The value of the lag coefficient $\left(D R_{\text {lag }}\right)$ ranges from 1 to 12 and should be provided by the user after investigating watershed characteristics or related documents. The time of concentration is defined as the time required for water to flow from a remote point in a watershed to a watershed outlet. The time of concentration is important in the rainfall runoff model and can be estimated from various formulas, although the variability of the estimates of the time of concentration given by various formulas can be high [40]. There are two types of time of concentration: the time required for overland flow and the time required for channel flow. These are calculated from watershed-specific information, such as the average slope $(\mathrm{m} / \mathrm{m})$, the slope length $(\mathrm{m})$, the channel length from the most distant point to the subbasin outlet $(\mathrm{km})$ and Manning's coefficient, $n$, as shown in Equations (6) and (7) $[38,41]$. Equations (4) and (5) were added to the direct runoff module of the watershed-scale L-THIA ACN model.

$$
\begin{gathered}
\mathrm{TC}_{o}=\frac{\text { slope }_{\text {slo }} \cdot n^{0.6}}{18 \cdot \text { Slope }^{0.3}} \\
T C_{c}=\frac{0.62 \cdot L \cdot n_{c}^{0.75}}{\text { Area }^{0.125} \cdot \text { Slope }_{C}{ }^{0.375}}
\end{gathered}
$$

In these equations, $T C_{O}$ is the time of concentration for overland flow $(\mathrm{h}) ; T C_{C}$ is the time of concentration for channel flow (h); $L_{\text {Slope }}$ is the HRU slope length (m); $n$ is Manning's coefficient for overland flow; $n_{C}$ is Manning's coefficient for channel flow; Slope is the average slope of the HRU $(\mathrm{m} / \mathrm{m})$; Slope $_{C}$ is the channel slope $(\mathrm{m} / \mathrm{m}) ; \mathrm{L}$ is the channel length from the most distant point to the subbasin outlet $(\mathrm{km})$; and Area is the area of the HRU $\left(\mathrm{km}^{2}\right)$. 
In this study, the values of Manning's coefficient from Table 2 were used for the calculation of $T C_{O}$, and the values of Manning's coefficient for $T C_{C}$ were calibrated based on the land cover and the parameter range, based on Table 2. The Slope, the Area of the HRU and the channel length $L$ from the most distant point to the subbasin outlet $(\mathrm{km})$ were calculated using a GIS tool for the purpose of computing the time of concentration for overland flow and the time of concentration for channel flow.

Table 2. Manning's roughness coefficient, $n$, for overland flow [42].

\begin{tabular}{ccc}
\hline Land Cover & Median & Range \\
\hline Fallow, no residue & 0.010 & $0.008-0.012$ \\
Conventional tillage, no residue & 0.090 & $0.060-0.120$ \\
Conventional tillage, residue & 0.190 & $0.16-0.220$ \\
Chisel plow, no residue & 0.090 & $0.060-0.120$ \\
Chisel plow, residue & 0.130 & $0.100-0.160$ \\
Fall disking, residue & 0.400 & $0.300-0.500$ \\
No till, no residue & 0.070 & $0.040-0.100$ \\
No till, 0.5-1 t/ha residue & 0.120 & $0.070-0.170$ \\
No till, 2-9 t/ha residue & 0.300 & $0.170-0.470$ \\
Rangeland, 20\% cover & 0.600 & - \\
Short-grass prairie & 0.150 & $0.100-0.200$ \\
Dense grass & 0.240 & $0.170-0.300$ \\
Bermuda grass & 0.410 & $0.300-0.480$ \\
\hline
\end{tabular}

However, because the calculation of the slope length is strongly affected by the digital elevation model (DEM) cell size, the field slope length can be overestimated when it is calculated using a GIS tool [43]. Furthermore, the DEM resolution, slope length, river networks and flow length estimation are among the major source of uncertainties in rainfall-runoff modeling [44]. Thus, in this study, the slope length of each HRU was calculated from the relationship between the field slope length and the average field slope, as proposed in [45]. This relationship between the field slope length and the average field slope (Table 3) was added to the direct runoff module in the watershed-scale L-THA ACN model. However, this relationship, described in Table 3, was obtained from measurements made in the USA. Thus, to reflect local field slope length properties, an additional parameter (SLSUB) was added to adjust the slope length.

Table 3. Suggested maximum slope length for field slope for contouring [45].

\begin{tabular}{cc}
\hline Land Slope (\%) & Maximum Length (m) \\
\hline $1-2$ & 122 \\
$3-5$ & 91 \\
$6-8$ & 61 \\
$9-12$ & 37 \\
$13-16$ & 24 \\
$17-20$ & 18 \\
$21-25$ & 15 \\
\hline
\end{tabular}

After calculation of the direct runoff for each HRU released to the stream, the direct runoff of each subbasin was calculated by summing the direct runoff from all HRUs within each subbasin (Equation (8)):

$$
Q_{D R, s u b}=\sum_{H R U=1}^{n} Q_{D R, H R U}
$$

where $Q_{D R, s u b}$ is the amount of direct runoff generated in the subbasin on a given day (mm). 


\subsubsection{Development of Baseflow Module}

The NRCS-CN method and LC-ACN-REs are both used for direct runoff estimation, but not for baseflow computation for a watershed. The baseflow component was developed and linked to the watershed-scale L-THIA ACN model for use in watershed hydrology studies, as well as evaluation of the water quality of a watershed.

According to Dingman [46], the aquifer in a watershed is composed of two aquifers, an unconfined aquifer and a confined aquifer. Water recharged into an unconfined aquifer contributes to flow in the main channel and influences the amount of streamflow, while water recharge into a confined aquifer is assumed to flow somewhere outside of the watershed [47].

Based on the user-defined fraction of infiltrated water flowing into the confined aquifer from each HRU, the amount of infiltrated water flowing into the unconfined aquifer can be estimated. The baseflow module, which was developed and integrated into the watershed-scale L-THIA ACN model, simulates these processes to account for the baseflow contribution to streamflow in a watershed. The water balance in an unconfined aquifer is calculated according to Equation (9):

$$
a q f_{H R U, i}=a q f_{H R U, i-1}+\omega_{\text {unconf }, H R U}-Q_{B F, H R U}
$$

where $a q f_{H R U, i}$ is the amount of water stored in an unconfined aquifer on a given day $(\mathrm{mm}), a q f_{H R U, i-1}$ is the amount of water stored in the unconfined aquifer on the previous day $(\mathrm{mm}), \omega_{\text {unconf,HRU }}$ is the amount of recharge entering the unconfined aquifer on that day $(\mathrm{mm})$ and $Q_{B F, H R U}$ is the amount of baseflow into the main channel ( $\mathrm{mm}$ ).

The amount of water recharged into both aquifers (confined and unconfined) is estimated using the exponential decay weighting function (Equation (10)) proposed by Venetis [48] and used by Sangrey et al. [49] in their precipitation-groundwater response model and by Neitsch et al. [38] in the SWAT model:

$$
\omega_{\text {rchrg }, H R U, i}=\left[1-\exp \left(\frac{-1}{B F_{\text {delay }}}\right)\right] \times F_{H R U, i}+\exp \left(\frac{-1}{B F_{\text {delay }}}\right) \times \omega_{\text {rchrg }, H R U, i-1}
$$

where $\omega_{\text {rcharg }, H R U, i}$ is the amount of recharge entering both aquifers on a given day $(\mathrm{mm}), B F_{\text {delay }}$ is the delay time in aquifer recharge once the water infiltrates from the surface (days), $F_{H R U, i}$ is the amount of infiltration on the given day $(\mathrm{mm})$ and $\omega_{\text {rcharg }{ }_{,} H R U, i-1}$ is the amount of recharge that enters the aquifers on the previous day $(\mathrm{mm})$.

The amount of infiltration on a given day is calculated using Equation (11), which is modified from that used in the NRCS-CN method [22] and was used by Kim et al. [50] to estimate the CN-based infiltration and baseflow:

$$
F_{h r u, i}=\frac{S\left(P-I_{a}\right)}{P-I_{a}+S}, I_{a}=0.2 S, S=\frac{25400}{A d j \_C N_{H R U, A C N}}-254
$$

where $F_{H R U, i}$ is the amount of infiltration on a given day $(\mathrm{mm}), S$ is the is the potential maximum retention (mm), $P$ is the rainfall $(\mathrm{mm}), A d j_{-} C N_{H R U}, A C N$ is the $C N$ value determined from the extended LC-ACN-REs and $I_{a}$ is the initial abstraction $(\mathrm{mm})$.

In the baseflow module, only a fraction of the infiltrated water is assumed to flow into the unconfined aquifer, based on the user-defined fraction of infiltrated water flowing into the confined aquifer (Equations (12) and (13)):

$$
\begin{gathered}
\omega_{\text {conf }, H R U}=F r_{\text {conf }} \times \omega_{\text {rchrg }, H R U} \\
\omega_{\text {unconf }, H R U}=\omega_{\text {rchrg }, H R U}-\omega_{\text {conf }, H R U}
\end{gathered}
$$


where $\omega_{\text {conf,HRU }}$ is the amount of infiltrated water flowing into a confined aquifer on a given day $(\mathrm{mm}), F r_{\text {conf }}$ is the fraction of water flowing into the confined aquifer and $\omega_{\text {unconf,HRU }}$ is the amount of recharge entering the unconfined aquifer on that day $(\mathrm{mm})$.

The amount of water flowing into an unconfined aquifer contributes to baseflow only if the amount of water in the unconfined aquifer exceeds a threshold value specified by the user that depends on the aquifer's characteristics. The steady-state response of the baseflow is expressed by Equation (14) [51]:

$$
Q_{B F, H R U}=\frac{8000 \times k_{s a t}}{L^{2} B F} \times h_{w t b l}
$$

where $Q_{B F, H R U}$ is the amount of baseflow into the main channel $(\mathrm{mm}), k_{s a t}$ is the hydraulic conductivity of the aquifer (mm/day), $L_{B F}$ is the distance from the ridge or subbasin divide for the baseflow to the main channel (m) and $h_{w t b l}$ is the water table height (m).

The water table height $\left(h_{w t b l}\right)$ depends on the baseflow response in the non-steady state and is calculated using Equation (15) [52]:

$$
\frac{d h_{w t b l}}{d t}=\frac{\omega_{\text {unconf }, H R U}-Q_{B F, H R U}}{800 \times \mu}
$$

where $\frac{d h_{w+b l}}{d t}$ is the change in the elevation of the water table (mm/day), $\omega_{\text {unconf,HRU }}$ is the amount of recharge entering the unconfined aquifer on a given day $(\mathrm{mm}), Q_{B F, H R U}$ is the baseflow into the main channel on that day $(\mathrm{mm})$ and $\mu$ is the specific yield of the unconfined aquifer $(\mathrm{m} / \mathrm{m})$.

Combining Equations (14) and (15) yield Equation (16) [38]:

$$
\frac{d Q_{B F, H R U}}{d t}=10 \times \frac{k_{s a t}}{\pi \times L^{2} B F} \times\left(\omega_{\text {unconf }, H R U}-Q_{B F, H R U}\right)=\alpha_{B F} \times\left(\omega_{\text {unconf }, H R U}-Q_{B F, H R U}\right)
$$

where $Q_{B F, H R U}$ is the baseflow into the main channel on a given day $(\mathrm{mm}), k_{\text {sat }}$ is the hydraulic conductivity of the aquifer (mm/day), $L_{B F}$ is the distance from the ridge or subbasin divide for the baseflow to the main channel $(\mathrm{m}), \mu$ is the specific yield of the unconfined aquifer $(\mathrm{m} / \mathrm{m}), \omega_{\text {unconf,HRU }}$ is the amount of recharge entering the unconfined aquifer on that day $(\mathrm{mm})$ and $\alpha_{B F}$ is the baseflow recession constant.

After integrating and rearranging Equation (14), $Q_{B F}, H R U$ can be expressed by Equation (17) [38]:

$$
\begin{aligned}
& Q_{B F, H R U, i}=Q_{B F, H R U, i-1} \times \exp \left[-\alpha_{B F} \times \Delta t\right]+\omega_{\text {unconf }, H R U} \times\left(1-\exp \left[-\alpha_{B F} \times \Delta t\right]\right), \text { if aqf }>a q f_{\text {thr }} \\
& Q_{B F, H R U, i}=0, \text { if } a q f<a q f_{\text {thr }}
\end{aligned}
$$

where $Q_{B F, H R U, i}$ is the baseflow into the main channel on a given day (mm), $Q_{B F, H R U, i-1}$ is the baseflow into the main channel on the previous day, $\alpha_{B F}$ is the baseflow recession constant, $\omega_{\text {unconf,HRU }}$ is the amount of recharge entering the unconfined aquifer on the given day $(\mathrm{mm}), \Delta t$ is the time step (one day), aqf is the amount of water stored in the unconfined aquifer on the given day ( $\mathrm{mm}$ ) and $a q f t h r$ is the threshold water level in the unconfined aquifer for baseflow contribution to the main channel to occur (mm).

The baseflow recession constant $\left(\alpha_{B F}\right)$ in Equation (17) reflects the baseflow response to the amount of recharge [52]. Values between 0.1 and 0.3 represent slow response conditions in a watershed, and values between 0.9 and 1.0 represent rapid response conditions [38,52]. Two options (simple long-term daily average and daily time series point source capabilities) were enabled in the direct runoff module to simulate the effects of discharge from Waste Water Plants (WWP) or other point sources on watershed hydrology and water quality.

\subsubsection{Development of Channel Routing Module}

Streamflow flows downward and meets flow from other upper streams in channel networks. The amount of streamflow in a watershed is affected by various mechanisms. In this study, a channel 
routing module was integrated into the watershed-scale L-THIA ACN model for simulation of flow routing using the Muskingum routing method [53]. The Muskingum routing method estimates the storage volume in a channel length as a combination of wedge and prism storage [53]. The concept of the Muskingum routing method is illustrated in Figure 3. The first case represents the storage in the river during the rising limb of a hydrograph; the second case represents uniform flow; and the third case represents the storage during the falling limb of the hydrograph. This hysteresis might cause different flood wave speeds during the rising and falling limbs of the hydrograph [54].

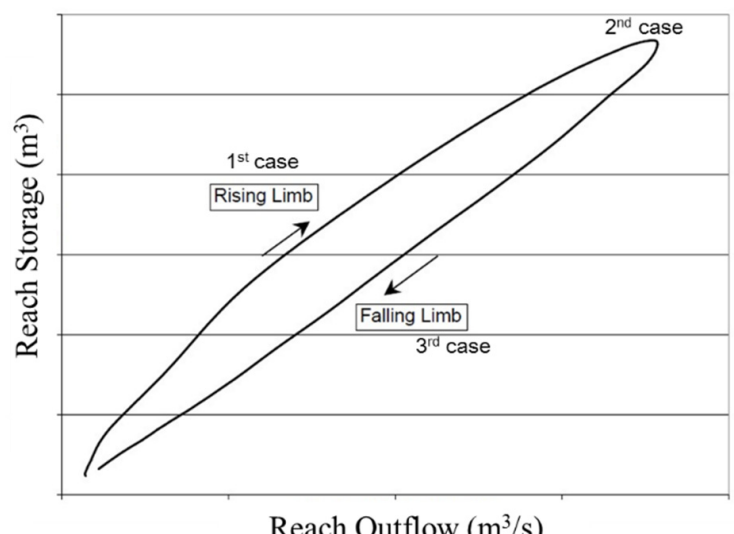

Figure 3. Storage in a river reach versus reach outflow [54].

The effects of these variables and the reach storage-discharge relationship are expressed by the equation used in the Muskingum routing method to estimate the reach storage volume, $V_{\text {stor }}$ :

$$
V_{\text {stor }}=K\left(X q_{\text {in }}+(1-X) q_{\text {out }}\right)
$$

where $V_{\text {stor }}$ is the reach storage volume $\left(\mathrm{m}^{3} / \mathrm{s}\right), K$ is the storage time constant for the reach $(\mathrm{s}), X$ is the weighting factor, $q_{\text {in }}$ is the inflow rate $\left(\mathrm{m}^{3} / \mathrm{s}\right)$ and $q_{\text {out }}$ is the outflow rate $\left(\mathrm{m}^{3} / \mathrm{s}\right)$.

Equations (18) and (19), proposed by Williams [55], can be combined and simplified as Equation (20):

$$
\begin{gathered}
\Delta t\left(\frac{q_{\text {in }}+q_{\text {in }, \Delta t}}{2}\right)-\Delta t\left(\frac{q_{\text {out }}+q_{\text {out }, \Delta t}}{2}\right)+V_{\text {stor }}=V_{\text {stor }, \Delta t} \\
q_{\text {out }, \Delta t}=C_{1} q_{\text {in }, \Delta t}+C_{2} q_{\text {in }}+C_{3} q_{o u t}
\end{gathered}
$$

where $q_{i n}$ is the inflow rate at the beginning of the time step $\left(\mathrm{m}^{3} / \mathrm{s}\right), q_{i n, \Delta t}$ is the inflow rate at the end of the time step $\left(\mathrm{m}^{3} / \mathrm{s}\right), q_{\text {out }}$ is the outflow rate at the beginning of the time step $\left(\mathrm{m}^{3} / \mathrm{s}\right)$, $q_{\text {out }, \Delta t}$ is the outflow rate at the end of the time step $\left(\mathrm{m}^{3} / \mathrm{s}\right)$ and $C 1, C 2$ and $C 3$ are expressed by Equations (21)-(23), respectively.

$$
\begin{aligned}
& C_{1}=\frac{\Delta t-2 \times K \times X}{2 \times K \times(1-X)+\Delta t} \\
& C_{2}=\frac{\Delta t+2 \times K \times X}{2 \times K \times(1-X)+\Delta t} \\
& C_{3}=\frac{2 \times K \times(1-X)-\Delta t}{2 \times K \times(1-X)+\Delta t}
\end{aligned}
$$

The value for the weighting factor, $X$, is a user input. The value of the storage time constant, $K$, is calculated using Equation (24):

$$
K=M k 1 \times \text { bankfull }+M k 2 \times \text { bankfull } 0.1
$$


where $K$ is the storage time constant for a reach segment (s), $M k 1$ and $M k 2$ are weighting factors input by the user, bankfull is the storage time constant estimated for the reach segment with bankfull flows (s) and bankfull 0.1 is the storage time constant estimated for the reach segment with one tenth of the bankfull depth (s).

The value of bankfull can be calculated using Equation (25) [38,53]:

$$
\text { bankfull }=\frac{1000 \times L_{\text {reach }}}{c}
$$

where bankfull is the storage time constant estimated for the reach segment with bankfull flows (s), $L_{\text {reach }}$ is the stream length $(\mathrm{m})$ and $c$ is the celerity corresponding to the flow for the specified depth (m/s).

The value of $c$ can be determined from Equation (26), using the cross-sectional area of the stream and Manning's equation [38]:

$$
c=\frac{d}{d A}\left(q_{c h}\right)=\frac{5}{3}\left(\frac{R^{\frac{2}{3}} \times I^{\frac{1}{2}}}{n}\right)=\frac{3}{5} \cdot v_{c}
$$

where $A$ is the cross-sectional area of flow in the stream $\left(\mathrm{m}^{2}\right), q_{c h}$ is the flow rate in the stream $\left(\mathrm{m}^{3} / \mathrm{s}\right)$, $R$ is the hydraulic radius for a given depth of flow $(\mathrm{m}), I$ is the slope $(\mathrm{m} / \mathrm{m})$ and $n$ is Manning's coefficient for the channel.

To calculate $V_{c}$ in Equation (26), the metacenter of the streams should be evaluated, and the actual shapes of all of the streams in each subbasin should be measured. However, it would be difficult to measure the cross-sections of all of the streams. In this study, all streams in subbasins were assumed to be trapezoidal channels with side slopes of 0.5 , and the slope of the flood plain was assumed to be 0.25 . These assumptions are similar to those made in the SWAT model [38].

\subsection{Input Parameters of Watershed-Scale L-THIA ACN Model}

The watershed-scale L-THIA ACN model was developed to estimate streamflow using direct runoff, baseflow and channel routing modules.

The parameters of these three modules consist of $\mathrm{CN}$ parameters for all HRUs, two direct runoff parameters, four baseflow parameters and three channel routing parameters, as summarized in Table 4. The watershed-scale L-THIA ACN model requires a smaller number of parameters than other watershed models, such as SWAT and HSPF.

\begin{tabular}{|c|c|c|c|}
\hline $\begin{array}{l}\text { Calibration } \\
\text { Component }\end{array}$ & $\begin{array}{l}\text { Calibration } \\
\text { Parameter }\end{array}$ & Description of Parameter & $\begin{array}{l}\text { Range of } \\
\text { Parameter }\end{array}$ \\
\hline \multirow{3}{*}{ Direct runoff } & $A d j \_C N^{(1)}$ & Adjusted coefficient for $\mathrm{CN}$ & $-0.1-0.1$ \\
\hline & $D R_{\text {lag }}(1)$ & Direct runoff lag coefficient & $1-12$ \\
\hline & $S L S U B^{(2)}$ & Adjustment for slope length & $-10-10$ \\
\hline \multirow{3}{*}{ Baseflow } & $\alpha_{B F}(1)$ & Baseflow recession constant & $0.1-1.0$ \\
\hline & $F r_{\text {conf }}(1)$ & Fraction of water flowing into confined aquifer & $0.0-0.9$ \\
\hline & $a q f_{t h r}(1)$ & $\begin{array}{l}\text { Threshold water level in the unconfined aquifer } \\
\text { for baseflow contribution ( } \mathrm{mm})\end{array}$ & $0.0-5000$ \\
\hline \multirow{4}{*}{$\begin{array}{l}\text { Channel } \\
\text { routing }\end{array}$} & $B F_{\text {delay }}{ }^{(1)}$ & $\begin{array}{l}\text { Delay time for aquifer recharge after water } \\
\text { infiltration from surface (day) }\end{array}$ & $1-10$ \\
\hline & $M K 1^{(1)}$ & $\begin{array}{l}\text { Weighting factor for influence of normal flow } \\
\text { on storage time constant value }\end{array}$ & $0.1-0.9$ \\
\hline & $M k 2^{(1)}$ & $\begin{array}{l}\text { Weighting factor for influence of low flow on } \\
\text { storage time constant value }\end{array}$ & $0.1-0.9$ \\
\hline & $M k x^{(1)}$ & Weighting factor for Muskingum method & $0.1-0.9$ \\
\hline
\end{tabular}

Table 4. Parameters used in the watershed-scale L-THIA ACN model.

Note: (1) constant value; (2) multiplied value. 


\subsection{Applications of Watershed-Scale L-THIA ACN Model}

The watershed-scale L-THIA ACN model, developed in this study, was applied to four watersheds (Goboo A, Tancheon A, Kumbon A and Pyungchang A) in South Korea, where TMDLs have been implemented to evaluate the water quality achieved with various management practices (Figure 4).

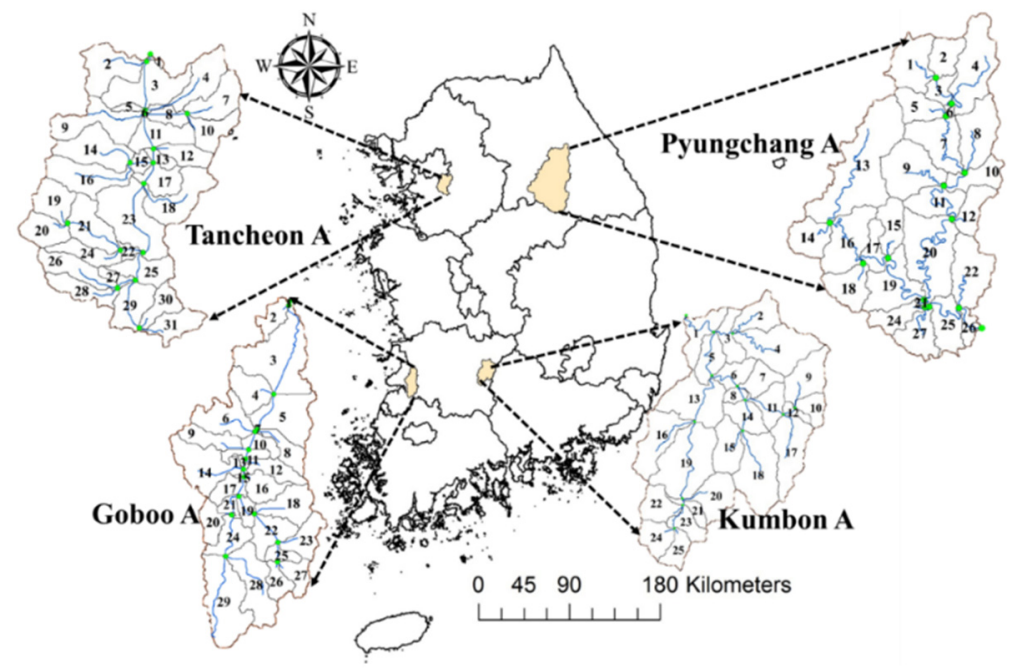

Figure 4. Four study watersheds for evaluation of watershed-scale L-THIA ACN model.

Among the four watersheds, the Goboo A watershed $\left(231.9 \mathrm{~km}^{2}\right)$ has a somewhat flatter topography, with average slopes $(5.0 \%)$. The land cover distribution is forest $(13.6 \%)$, urban $(5.7 \%)$, agricultural $(71.6 \%)$, pasture $(3.7 \%)$, bare land $(0.9 \%)$ and other $(4.6 \%)$. The areas of the Tancheon A, Kumbon A and Pyungchang A watersheds are 203.9, 289.3 and $1756.9 \mathrm{~km}^{2}$, respectively, and the average slopes of these three watersheds are $14.6,25.7$ and $30.8 \%$, respectively.

The land cover distributions of the Tancheon A, Kumbon A and Pyungchang A watersheds are forest (50.3, 65.9 and $80.5 \%$, respectively), urban (25.3, 2.7 and $1.7 \%$, respectively), agricultural $(5.3,20.8$ and $12.8 \%$, respectively), pasture $(13.8,7.7$ and $2.0 \%$, respectively), bare land $(3.9,1.4$ and $1.2 \%$, respectively) and other (1.3, 1.6 and 1.9, respectively). The Goboo A, Tancheon A and Kumbon A watersheds are headwater watersheds. The Pyungchang A watershed is considerably larger than these other three watersheds and includes the Jucheon A headwater watershed.

The watershed-scale L-THIA ACN model requires daily rainfall data, as well as HRU maps, which are prepared from combinations of subbasin, land cover and soil maps. Subbasin maps were delineated by 30-m resolution DEM and stream data using the ArcGIS watershed delineation geoprocessing tool. HRU maps were created by combining subbasin maps, reconnaissance soil maps and land cover maps provided by the Ministry of Environment of South Korea.

Daily streamflows for 1 January 2010-31 December 2014 were estimated for the four watersheds using the watershed-scale L-THIA ACN model and precipitation data from the Korean Meteorological Administration (KMA). The watershed-scale L-THIA ACN model was calibrated and validated by adjusting the parameters of the direct runoff and baseflow to fit the simulated daily streamflows for eight-day intervals to observed streamflow data. The calibration period was 1 January 2008-31 December 2010 and the validation period was 1 January 2011-12 December 2014.

\section{Results and Discussion}

\subsection{Result of Extended LC-ACN-RE Approach for the Consideration of HSGs}

In this study, thirteen land cover-based asymptotic CN regression equations (LC-ACN-REs) were extended to 52 regression equations to consider HSGs, using the ratio of CN for a given HSG in 
the NEH-4 CN table (Table 5). Thus, the CN values for each HSG group can be estimated with the 52 extended LC-ACN-REs. These $\mathrm{CN}$ values were used to estimate the direct runoff, the infiltration from each HRU and the baseflow component.

Table 5. Parameters of extended LC-ACN-REs with HSG considered.

\begin{tabular}{|c|c|c|c|c|}
\hline \multirow{2}{*}{ Land Cover } & \multirow{2}{*}{ Soil Type } & \multicolumn{3}{|c|}{ Asymptotic CN Regression } \\
\hline & & $C N_{\infty}$ & $100-C N_{\infty}$ & $\mathbf{K}$ \\
\hline \multirow{4}{*}{ Residential area } & A & 74.43 & 25.57 & 0.0417 \\
\hline & $\mathrm{B}$ & 82.20 & 17.80 & 0.0124 \\
\hline & C & 86.72 & 13.28 & 0.0059 \\
\hline & $\mathrm{D}$ & 88.61 & 11.39 & 0.0048 \\
\hline \multirow{4}{*}{ Manufacturing area } & A & 60.69 & 39.31 & 0.0282 \\
\hline & $\mathrm{B}$ & 67.69 & 32.31 & 0.0169 \\
\hline & C & 70.69 & 29.31 & 0.0128 \\
\hline & $\mathrm{D}$ & 72.70 & 27.30 & 0.0104 \\
\hline \multirow{4}{*}{ Commercial area } & A & 86.19 & 13.81 & 0.0593 \\
\hline & B & 89.09 & 10.91 & 0.0376 \\
\hline & C & 91.03 & 8.97 & 0.0263 \\
\hline & $\mathrm{D}$ & 92.00 & 7.47 & 0.0185 \\
\hline \multirow{4}{*}{ Recreational facility area } & A & 80.29 & 19.71 & 0.0677 \\
\hline & B & 83.00 & 17.00 & 0.0550 \\
\hline & C & 84.80 & 15.20 & 0.0427 \\
\hline & $\mathrm{D}$ & 85.70 & 14.30 & 0.0428 \\
\hline \multirow{4}{*}{ Road } & A & 66.27 & 33.73 & 0.0110 \\
\hline & B & 66.27 & 33.73 & 0.0110 \\
\hline & $\mathrm{C}$ & 66.27 & 33.73 & 0.0110 \\
\hline & $\mathrm{D}$ & 66.27 & 33.73 & 0.0110 \\
\hline \multirow{4}{*}{ Paddy } & A & 55.34 & 44.66 & 0.0515 \\
\hline & B & 63.37 & 36.63 & 0.0312 \\
\hline & $\mathrm{C}$ & 69.62 & 30.38 & 0.0224 \\
\hline & $\mathrm{D}$ & 72.30 & 27.70 & 0.0191 \\
\hline \multirow{4}{*}{ Upland } & A & 38.84 & 61.16 & 0.0144 \\
\hline & B & 47.84 & 52.16 & 0.0077 \\
\hline & $\mathrm{C}$ & 54.84 & 45.16 & 0.0044 \\
\hline & $\mathrm{D}$ & 57.84 & 42.16 & 0.0033 \\
\hline \multirow{4}{*}{ Green house } & A & 41.34 & 58.66 & 0.0355 \\
\hline & B & 47.35 & 52.65 & 0.0198 \\
\hline & C & 52.13 & 47.87 & 0.0123 \\
\hline & $\mathrm{D}$ & 54.13 & 45.87 & 0.0077 \\
\hline \multirow{4}{*}{ Orchard } & A & 48.77 & 51.23 & 0.0274 \\
\hline & B & 55.84 & 44.16 & 0.0204 \\
\hline & $\mathrm{C}$ & 61.35 & 38.65 & 0.0157 \\
\hline & $\mathrm{D}$ & 63.71 & 36.29 & 0.0176 \\
\hline \multirow{4}{*}{ Forest } & A & 36.07 & 63.93 & 0.0362 \\
\hline & B & 52.91 & 47.09 & 0.0274 \\
\hline & C & 60.46 & 39.54 & 0.0141 \\
\hline & $\mathrm{D}$ & 64.84 & 35.16 & 0.0117 \\
\hline \multirow{4}{*}{ Pasture } & A & 22.99 & 75.77 & 0.0181 \\
\hline & B & 34.09 & 65.91 & 0.0164 \\
\hline & C & 40.33 & 59.67 & 0.0164 \\
\hline & $\mathrm{D}$ & 43.95 & 56.05 & 0.0164 \\
\hline \multirow{4}{*}{ Bare land } & A & 74.76 & 25.24 & 0.0200 \\
\hline & B & 82.59 & 17.41 & 0.0092 \\
\hline & C & 87.13 & 12.87 & 0.0072 \\
\hline & $\mathrm{D}$ & 89.91 & 10.09 & 0.0066 \\
\hline
\end{tabular}

The 52 extended regression equations predict the lowest asymptotic $\mathrm{CN}$ values for high-permeability soils of the HSG A type and the highest asymptotic $\mathrm{CN}$ values for low-permeability 
soils of the HSG D type. The highest asymptotic CN value predicted by these equations was 92.0 for commercial areas, and the lowest asymptotic $\mathrm{CN}$ value was 23.0 for pasture.

\subsection{Application of the Watershed-Scale L-THIA ACN Model}

The watershed-scale L-THIA ACN model was calibrated using observed streamflow data for the four study watersheds in South Korea. The calibrated values of the ten parameters for each study watershed are shown in Table 6.

Table 6. Calibrated and validated model parameters for streamflow simulation using the watershedscale L-THIA ACN model.

\begin{tabular}{|c|c|c|c|c|c|c|c|c|c|c|}
\hline Watershed & Adj_CN & SLSUB & $D R_{\text {lag }}$ & $\alpha_{B F}$ & $a q f_{\text {thr }}$ & $F r_{\text {conf }}$ & $B F_{\text {delay }}$ & $M k 1$ & $M k 2$ & $M k x$ \\
\hline Goboo A & -0.04 & 7.0 & 3 & 0.5 & 5.0 & 0.05 & 1 & 0.05 & 0.95 & 0.2 \\
\hline Tancheon A & 0.06 & 1.0 & 6 & 0.5 & 5.0 & 0.03 & 2 & 0.10 & 0.90 & 0.1 \\
\hline Kumbon A & 0.07 & 1.0 & 7 & 0.5 & 5.0 & 0.01 & 2 & 0.75 & 0.25 & 0.2 \\
\hline Pyungchang A & 0.09 & 1.0 & 10 & 0.5 & 150.0 & 0.10 & 5 & 0.05 & 0.95 & 0.2 \\
\hline
\end{tabular}

Among the ten parameters, $A d j \_C N$ and $D R_{\text {lag }}$ ranged from $-0.04-0.09$ and from 3-10, respectively. As the average slope of each watershed decreased, the Adj_CN parameter value also decreased, and the $D R_{\text {lag }}$ value increased. Thus, $A d j_{-C N}$ and $D R_{\text {lag }}$ should be adjusted for the average slope of a watershed before being used in the watershed-scale L-THIA ACN model. As described in the previous section, field slope lengths should be adjusted based on local conditions. For the Goboo A watershed, the SLSUB parameter, which is the adjusted slope length parameter, was found to be seven times greater than the default value.

The greater the area of a watershed is, the higher the threshold water level for baseflow $\left(a q f_{t h r}\right)$ in an unconfined aquifer is.

The $B F_{\text {delay }}$ parameter was found to exhibit the same trend as the $a q f_{t h r}$ parameter. The baseflow recession constant $\left(\alpha_{B F}\right)$ values were found to be similar for all four of the study watersheds. The baseflow response to main streamflow in the four watersheds constituted normal response conditions, as indicated by $\alpha_{B F}$ values from 0.4-0.6 (note that $\alpha_{B F}$ values of 0.1-0.3 represent a slow response, and $\alpha_{B F}$ values of $0.7-1.0$ represent a fast response) [52].

Comparisons of the simulation results and observed eight-day interval streamflows revealed reasonable agreement for the Goboo A watershed, with a coefficient of determination $\left(R^{2}\right)$ of 0.66 and Nash-Sutcliffe Efficiency (NSE) of 0.64. The $R^{2}$ values for Tancheon A, Kumbon A and Pyungchang A were $0.62,0.9$ and 0.62 , respectively, and the NSE values were $0.61,0.92$ and 0.60 , respectively (Figure 5 and Table 7).

Table 7. Results of streamflow estimation and comparison of observed and estimated values. NSE, Nash-Sutcliffe Efficiency.

\begin{tabular}{|c|c|c|c|c|c|c|c|c|}
\hline \multirow[t]{2}{*}{ Watershed } & \multicolumn{2}{|c|}{$\begin{array}{c}\text { Average Streamflow } \\
\text { (2008-2010, Calibration) }\end{array}$} & \multirow[t]{2}{*}{$\mathbf{R}^{2}$} & \multirow[t]{2}{*}{ NSE } & \multicolumn{2}{|c|}{$\begin{array}{c}\text { Average Streamflow } \\
(2011-2014, \text { Validation) }\end{array}$} & \multirow[t]{2}{*}{$\mathbf{R}^{2}$} & \multirow[t]{2}{*}{ NSE } \\
\hline & Obs. & Est. & & & Obs. & Est. & & \\
\hline Goboo A & 4.45 & 3.92 & 0.66 & 0.64 & 4.13 & 4.48 & 0.79 & 0.78 \\
\hline Tancheon A & 9.39 & 9.60 & 0.62 & 0.61 & 12.93 & 11.40 & 0.72 & 0.70 \\
\hline Kumbon A & 5.95 & 6.09 & 0.93 & 0.93 & 6.34 & 5.92 & 0.62 & 0.60 \\
\hline Pyungchang A & 34.38 & 36.74 & 0.62 & 0.60 & 53.69 & 51.35 & 0.80 & 0.79 \\
\hline
\end{tabular}




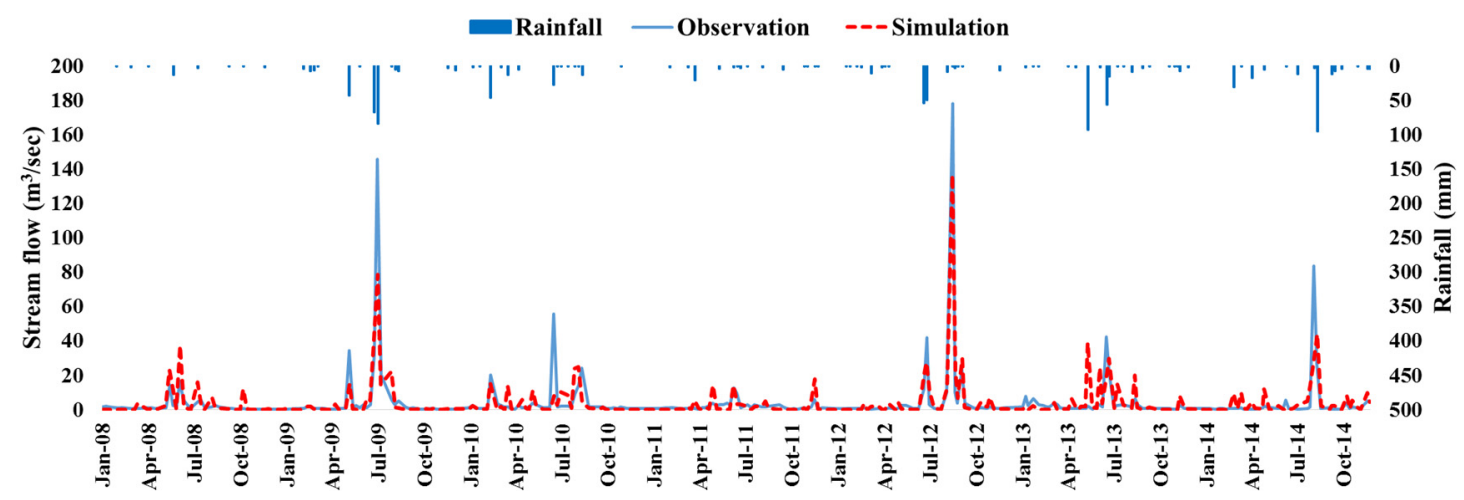

(a) Goboo A

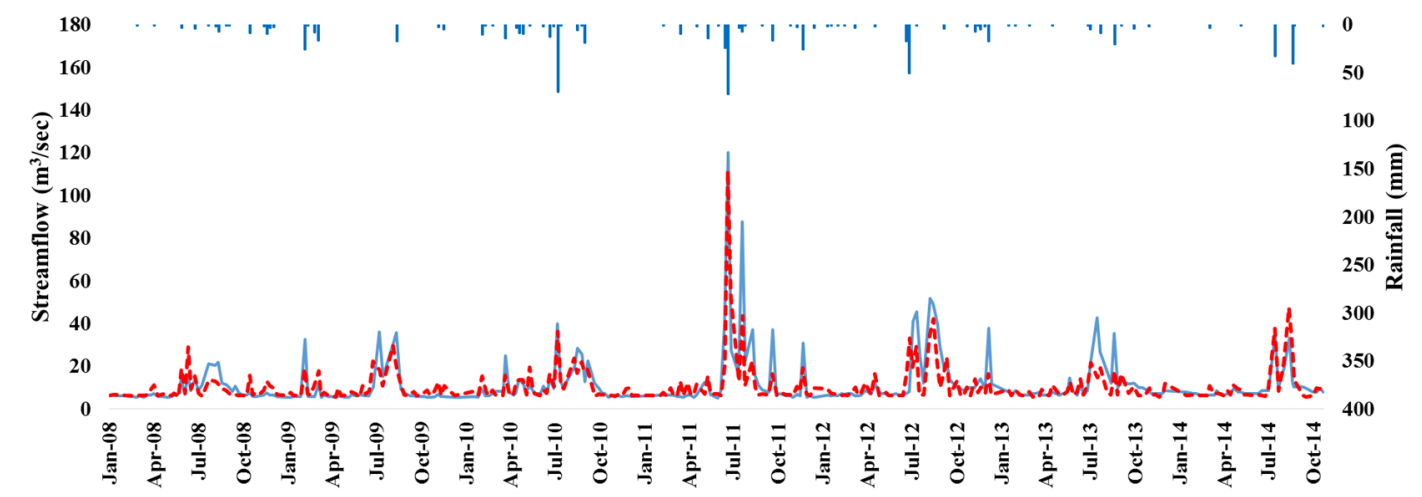

(b) Tancheon $\mathrm{A}$

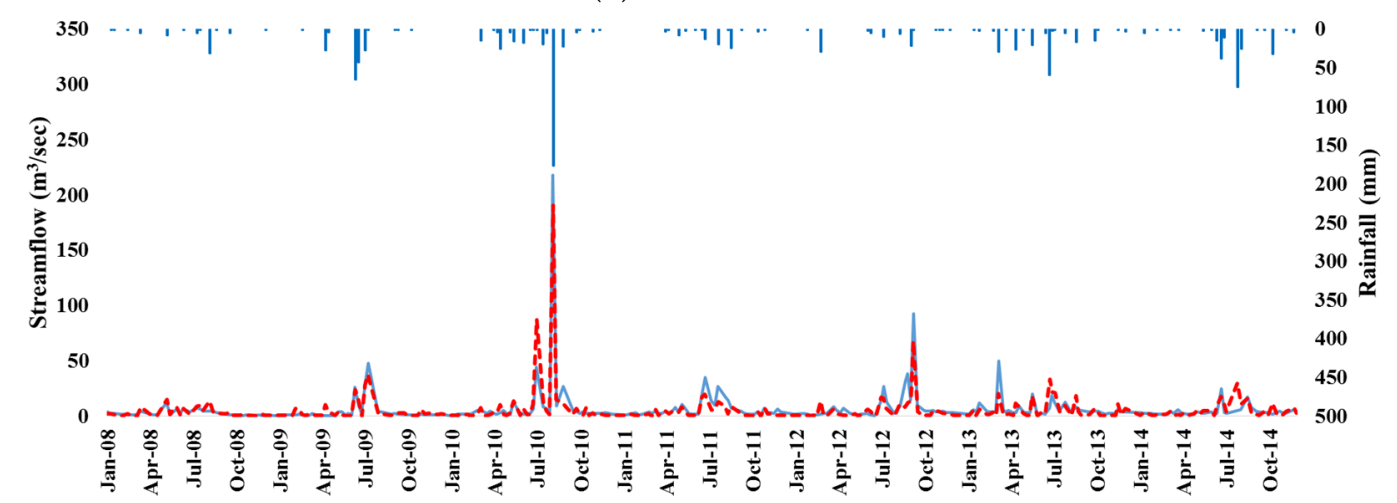

(c) Kumbon A

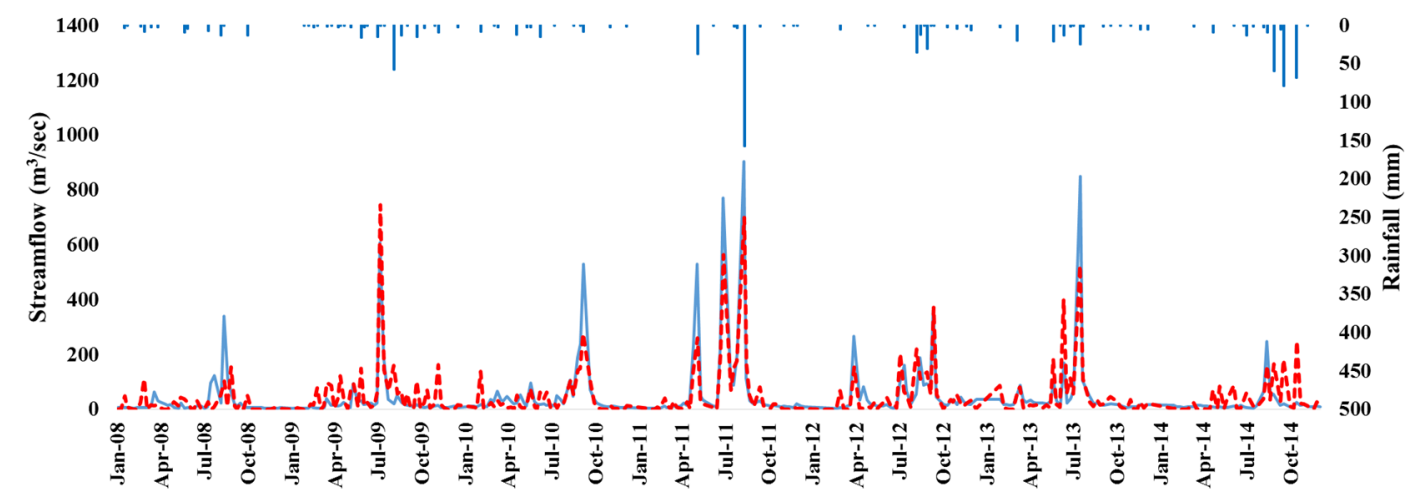

(d) Pyungchang A

Figure 5. Results of estimation of streamflow (2008-2014, eight-day interval). 
The validation results for the Goboo A watershed indicated that the $\mathrm{R}^{2}$ and NSE values were 0.79 and 0.78 , respectively. The $\mathrm{R}^{2}$ values for Tancheon A, Kumbon A and Pyungchang A were $0.72,0.62$ and 0.80 , respectively, and the NSE values were $0.70,0.60$ and 0.79 , respectively (Figure 5 and Table 7).

According to Ramanarayanan et al. [56] and Moriasi et al. [57], $R^{2}$ and NSE values that reflect satisfactory calibration of streamflow are $\mathrm{R}^{2} \geqslant 0.5$ and NSE $\geqslant 0.5$. By these criteria, the performance of the watershed-scale L-THIA ACN model developed in this study was acceptable, because the $\mathrm{R}^{2}$ and NSE values obtained from the calibration and validation were greater than 0.6 for all four study watersheds considered (Table 7).

There were no significant differences in the average streamflow for the study watersheds. The differences between the observed data and simulated streamflows in the calibration were 11.9, 2.2, 2.4 and $6.9 \%$ for the Goboo A, Tancheon A, Kumbon A and Pyungchang A watersheds, respectively, and the differences in the validation were 8.5, 11.8, 6.6 and 4.4\% (Table 7). As the results of this study show, the watershed-scale L-THIA ACN model can simulate streamflow well for watersheds ranging in size from $200.0 \mathrm{~km}^{2}-1756.9 \mathrm{~km}^{2}$.

As shown in Figure 5, the estimated peak flow during the high-flow season was lower than the observed peak flow. This can be explained by reduced infiltration, which is estimated using Equation (11). As the rainfall amount becomes greater, the $\mathrm{CN}$ estimated using the asymptotic $\mathrm{CN}$ approach becomes lower, resulting in a greater value of $S$ (the potential maximum retention, $\mathrm{mm}$ ). As $S$ becomes greater, the infiltration approaches zero, especially for forest and pasture land covers. This results in a lower baseflow contribution to the total streamflow. Similar issues have been mentioned in other studies [58,59]. Although Equation (11) is simple to use in estimating the contributions of infiltration and baseflow to streamflow using the $\mathrm{CN}$ value, more in-depth investigation is needed to account for the lower infiltration that occurs in land cover areas with lower $\mathrm{CN}$ values.

\section{Conclusions}

In this study, LC-ACN-REs were improved by enabling consideration of HSG characteristics. In addition, a watershed-scale L-THIA ACN model was developed with direct runoff, baseflow and channel routing capabilities integrated together. With this new L-THIA model, users can simulate streamflow (direct runoff + baseflow) in a watershed. Daily rainfall data, land cover and HSG maps, DEM and ten additional model parameters are needed for the simulation of streamflow.

The simulated streamflow agreed well with the observed streamflow for the four study watersheds (as indicated by $\mathrm{R}^{2}$ values in the range of $0.62-0.93$ and NSE values in the range of $0.60-0.93$ for both calibration and validation). These results demonstrate the predictive capability of the watershed-scale L-THIA ACN model developed in this study. Two model parameters (Adj_CN and $D R_{\text {lag }}$ ) were found to be closely related to the average field slope. Further in-depth investigation is needed to derive the relationships between the field slope length and these two model parameters. It should be noted that the watershed-scale L-THIA ACN model was not applied comprehensively to the watersheds for ranges of rainfall, land use, soil and topography conditions. It should also be noted that the values of the model parameters were estimated using manual calibration processes, which are affected by the subjective judgments of the model users.

For these reasons, automatic calibration using PARASOL (Parameter Solution), SUFI-2 (Sequential Uncertainty FItting algorithm), GLUE (Generalized Likelihood Uncertainty Estimation) and GA (Genetic algorithm) is needed for objective evaluation of the model parameters. With this function enabled, the relationship between the average field slope and the $A d j \_C N$ and $D R_{\text {lag }}$ parameters could be analyzed and utilized in the watershed-scale L-THIA ACN model for streamflow estimation in ungaged watersheds.

Acknowledgments: This research was supported by the Geo-Advanced Innovative Action (GAIA) Project (No. 2014000540003, Surface Soil Resources Inventory \& Integration (SSORII) Research Group) in South Korea.

Author Contributions: Jichul Ryu wrote the paper and developed the watershed-scale L-THIA ACN model. Won Seok Jang built the topography GIS data for study watersheds. Jonggun Kim applied and evaluated the 
model. Joong Dae Choi and Bernard A. Engel provided critical comments on and the revision of the manuscript. Jae E. Yang validated the model. Kyoung Jae Lim conceived of the idea for the project and provided many useful suggestions to improve the analysis of the results, as well as supervised the research.

Conflicts of Interest: The authors declare no conflict of interest.

\section{References}

1. Ma, F.; Ye, A.; Gong, W.; Mao, Y.; Miao, C.; Di, Z. An estimate of human and natural contributions to flood changes of the Huai River. Glob. PLanet. Change 2014, 119, 39-50. [CrossRef]

2. Yu, Q.; Wang, Y.; Xie, X.; Currell, M.; Pi, K.; Yu, M. Effects of short-term flooding on arsenic transport in groundwater system: A case study of the Datong Basin. J. Geochem. Explor. 2015, 158, 1-9. [CrossRef]

3. Stagge, J.H.; Kohn, I.; Tallaksen, L.M.; Stahl, K. Modeling drought impact occurrence based on meteorological drought indices in Europe. J. Hydrol. 2015, 530, 37-50. [CrossRef]

4. Logan, K.E.; Brunsell, N.A. Influence of drought on growing season carbon and water cycling with changing land cover. Agric. For. Meteorol. 2015, 213, 217-225. [CrossRef]

5. Martin, M.A.; Bourque, P.A. Mountain-river runoff components and their role in the seasonal development of desert-oases in northwest China. J. Arid Environ. 2015, 122, 1-15. [CrossRef]

6. Senaviratne, G.M.M.M.A.; Udawatta, R.P.; Anderson, S.H.; Baffaut, C.; Allen Thompson, A. Use of fuzzy rainfall-runoff predictions for clay pan watersheds with conservation buffers in Northeast Missouri. J. Hydrol. 2014, 517, 1008-1018. [CrossRef]

7. Lin, B.; Chen, X.; Yao, H.; Chen, Y.; Liu, M.; Gao, L.; James, A. Analyses of landuse change impacts on catchment runoff using different time indicators based on SWAT mode. Ecol. Indic. 2015, 58, 55-63. [CrossRef]

8. Holvoet, K.M.A.; Seuntjens, P.; Vanrolleghem, P.A. Monitoring and modeling pesticide fate in surface waters at the catchment scale. Ecol. Model. 2007, 209, 53-64. [CrossRef]

9. Jayakrishnan, R.S.R.S.; Srinivasan, R.; Santhi, C.; Arnold, J.G. Advances in the application of the SWAT model for water resources management. Hydrol. Proc. 2005, 19, 683-692. [CrossRef]

10. Gassman, P.W.; Reyes, M.R.; Green, C.H.; Arnold, J.G. The soil and water assessment tool: Historical development, applications, and future research directions. Trans. ASABE 2007, 50, 1211-1250. [CrossRef]

11. Meaurio, M.; Zabaleta, A.; Uriarte, J.A.; Srinivasan, R.; Antiguedad, I. Evaluation of SWAT models performance to simulate streamflow spatial origin. The case of a small forested watershed. J. Hydrol. 2015, 525, 326-324. [CrossRef]

12. Grimaldi, S.; Petroselli, A.; Serinaldi, F.A. Continuous Simulation Model for Design-Hydrograph Estimation in Small and Ungauged Watersheds. Hydrol. Sci. J. 2012, 57, 1035-1051. [CrossRef]

13. Grimaldi, S.; Petroselli, A.; Romano, N. Curve-Number/Green-Ampt mixed Procedure for Streamflow Predictions in Ungauged basins: Parameter Sensitivity Analysis. Hydrol. Proc. 2013, 27, 1265-1275. [CrossRef]

14. Arnold, J.G.; Moriasi, D.N.; Gassman, P.W.; Abbaspour, K.C.; White, M.J.; Srinivasan, R.; Santhi, C.; Harmel, R.D.; van Griensven, A.; Van Liew, M.W.; et al. SWAT: Model use, calibration and validation. Trans. ASABE 2012, 55, 1491-1508. [CrossRef]

15. Harbor, J. A practical method for estimating the impact of land use change on surface runoff. Groundwater Recharge and Wetland Hydrology. J. Am. Plan. Asssoc. 1994, 60, 91-104. [CrossRef]

16. Bhaduri, B.; Grove, M.; Lowry, C.; Harbor, J. Assessing the long-term hydrologic impact of land-use change: Cuppy McClure watershed, Indiana. J. Am. Water Works Assoc. 1997, 89, 94-106.

17. Lim, K.J.; Engel, B.A.; Tang, Z.; Muthukrishnan, S.; Choi, J.; Kim, K. Effects of calibration on L-THIA GIS runoff and pollutant estimation. J. Environ. Manag. 2006, 78, 35-43. [CrossRef] [PubMed]

18. U.S. Environmental Protection Agency (USEPA). SWMM 5 User's Manual; EPA/600/R-05/040; National Risk Management Research Laboratory, Office of Research and Development: Cincinnati, OH, USA, 2010.

19. Gironas, J.; Roesner, L.A.; Rossman, L.A.; Davis, J.A. New applications manual for the Storm Water Management Model (SWMM). Environ. Model. Softw. 2010, 25, 813-814. [CrossRef]

20. Tetra Tech. User's Guide Spreadsheet Tool for the Estimation of Pollutant Load (STEPL), Version 4.1; Tetra Tech: Fairfax, VA, USA, 2011.

21. Park, Y.S.; Engel, B.A. A web-based model to estimate the impact of best management practices. Water 2014, 6, 455-471. [CrossRef] 
22. Soil Conservation Service. (SCS). National Engineering Handbook; Section 4, Hydrology. US 444 Department of Agriculture, US Government Printing Office: Washington, DC, USA, 1972.

23. Engel, B.A. GIS-Based CN Runoff Estimation; Agricultural and Biological Engineering Departmental Report; Purdue University: West Lafayette, IN, USA, 1997.

24. Lim, K.J.; Engel, B.A.; Kim, Y.; Bhaduri, B.; Harbor, J. Development of the Long-Term Hydrologic Impact Assessment (L-THIA) WWW System. In Proceedings of the 10th International Soil Conservation, West Lafayette, IN, USA, 2 May 2002; Stott, D., Mohtar, R., Steinhardt, G., Eds.; Purdue University: West Lafayette, IN, USA, 2002; pp. 1018-1023.

25. Tang, Z.; Engel, B.A.; Lim, K.J.; Pijanowski, B.C.; Habor, J. Minimizing the Impact of urbanization on long term runoff. J. Am. Water Res. Assoc. 2005, 41, 1347-1359. [CrossRef]

26. Jang, C.H.; Kum, D.H.; Jung, Y.; Kim, K.; Shin, D.S.; Engel, B.A.; Shin, Y.; Lim, K.J. Development of a Web-based L-THIA 2012 direct runoff and pollutant Auto-calibration module using a genetic algorithm. Water 2013, 5, 1952-1963. [CrossRef]

27. Park, Y.S.; Lim, K.J.; Theller, L.; Engel, B.A. L-THIA GIS Manual; Agricultural and Biological Engineering Departmental Report; Purdue University: West Lafayette, IN, USA, 2013.

28. Ahiablame, L.M.; Engel, B.A.; Chaubey, I. Representation and evaluation of low impact development practices with L-THIA-LID: An example for site planning. Environ. Pollut. 2012, 1, 1-13. [CrossRef]

29. Ryu, J.; Jung, Y.; Kong, D.S.; Park, B.K.; Kim, Y.S.; Engel, B.A.; Lim, K.J. Approach of Land Cover based Asymptotic Curve Number Regression Equation to Estimate Runoff. J. Irrig. Drain. Eng. 2016. accepted.

30. Hawkins, R.H. Asymptotic determination of runoff curve numbers from data. J. Irrig. Drain. Eng. 1993, 119, 334-345. [CrossRef]

31. Tedela, N.M.; McCutcheon, S.C.; Rasmussen, T.C.; Hawkins, R.H.; Swank, W.T.; Campbell, J.L.; Adams, M.B.; Jackson, C.R.; Tollner, E.W. Runoff curve numbers for 10 small forested watersheds in the mountains of the eastern United States. J. Hydrol. Eng. 2012, 17, 1188-1198. [CrossRef]

32. Gundalia, M.; Dholakia, M. Impact of monthly curve number on daily runoff estimation for Ozat catchment in India. J. Mod. Hydrol. 2014, 4, 144-155. [CrossRef]

33. Banasik, K.; Woodward, D. Empirical determination of runoff curve number for a small agricultural watershed in Poland. In Proceedings of the 2nd Joint Federal Interagency Conference, Las Vegas, NV, USA, 27 June-1 July 2010.

34. Soulis, K.X.; Valiantzas, J.D.; Dercas, N.; Londra, P.A. Investigation of the Direct runoff Generation Mechanism for the Analysis of the SCS-CN method Applicability to a Partial area Experimental Watershed. Hydrol. Earth Syst. Sci. 2009, 13, 605-615. [CrossRef]

35. Soulis, K.X.; Valiantzas, J.D. SCS-CN parameter determination using rainfall-runoff data in heterogeneous watersheds-The Two-CN system approach. Hydrol. Earth Syst. Sci. 2012, 16, 1001-1015. [CrossRef]

36. Soulis, K.X.; Valiantzas, J.D. Identification of the SCS-CN Parameter Spatial Distribution using Rainfall-Runoff data in Heterogeneous Watersheds. Water Res. Manag. 2013, 27, 1737-1749. [CrossRef]

37. Ryu, J.; Kim, E.J.; Han, M.D.; Kim, Y.S.; Kum, D.H.; Lim, K.J.; Park, B.K. Enhancement of Estimation Method on the Land T-P Pollutant Load in TMDLs Using L-THIA. J. Korean Soc. Environ. Eng. 2014, 36, 162-171. [CrossRef]

38. Neitsch, S.L.; Arnold, J.G.; Kiniry, J.R.; Williams, J.R. Soil \& Water Assessment Theoretical Documentation Version 2005; Soil and Water Research Lavatory, Agricultural Research Service: Temple, TX, USA, 2005.

39. Huang, M.; Gallichand, J.; Wang, J.; Goulet, M. A modification to the Soil Conservation Service curve number method for steep slopes in the Loess Plateau of China. Hydrol. Proc. 2006, 20, 579-589. [CrossRef]

40. Grimaldi, S.; Petroselli, A.; Tauro, F.; Porfiri, M. Time of concentration: A paradox in modern hydrology. Hydrol. Sci. J. 2012, 57, 217-228. [CrossRef]

41. Hulsman, P. Determination of the Main Areas Contributing to the Suspended Sediment Load in the Mara River, Kenya. Master's Thesis, National University of Singapore, Singapore, 2015.

42. Engman, E.T. Roughness coefficient for routing surface runoff. J. Irrig. Drain. Eng. 1986, 112, 39-53. [CrossRef]

43. Hickey, R. Slope angle and slope length solutions for GIS. Cartography 2000, 29, 1-8. [CrossRef]

44. Petroselli, A. LIDAR data and Hydrological Applications at the basin scale. GISci. Remote Sens. 2012, 49, 139-162. [CrossRef] 
45. Wischmeier, W.H.; Smith, D.D. Predicting Rainfall Erosion Losses: A Guide to Conservation Planning. USDA Agricultural Handbook; No. 537; U.S. Gov. Print. Office: Washington, DC, USA, 1978.

46. Dingman, S.L. Physical Hydrology; Prentice-Hall, Inc.: Englewood Cliffs, NJ, USA, 1994.

47. Arnold, J.G.; Allen, P.M.; Bernhardt, G.A. Comprehensive surface groundwater flow model. J. Hydrol. 1993, 142, 47-69. [CrossRef]

48. Venetis, C. A study of the recession of unconfined aquifers. Bull. Int. Assoc. Sci. Hydrol. 1969, 14, 119-125. [CrossRef]

49. Sangrey, D.A.; Harrop-Williams, K.O.; Klaber, J.A. Predicting groundwater response to precipitation. J. Geotechnol. Geoenviron. Eng. 1984, 110, 957-975. [CrossRef]

50. Kim, H.W.; Sin, Y.J.; Choi, J.H.; Kang, H.W.; Ryu, J.; Lim, K.J. Estimation of CN-based infiltration and baseflow for effective watershed management. J. Korean Soc. Water Environ. 2011, 27, 405-412.

51. Hooghoudt, S.B. Bijdrage tot de kennis van enige natuurkundige grootheden van de ground. Versl. Landbouwkd. Onderz. 1940, 46, 515-707.

52. Smedema, L.K.; Rycroft, D.W. Land Drainage: Planning and Design of Agricultural Systems; Batsford Academic and Educational Ltd: London, UK, 1983.

53. Cunge, J.A. On the subject of flood propagation method (Muskingum method). J. Hydraul. Res. 1969, 7, 205-230. [CrossRef]

54. Boroughs, C.B.; Zagona, E.A. Daily flow routing with the Muskingum-Cunge method in the Pecos River Ware Model. In Proceedings of the Second Federal Interagency Hydrologic Modeling Conference, Las Vegas, NV, USA, 29 July-1 August 2002.

55. Williams, J.R. Flood routing with variable travel time or variable storage coefficients. Trans. ASAE 1969, 12, 100-103. [CrossRef]

56. Ramanarayanan, T.S.; Williams, J.R.; Dugas, W.A.; Hauck, L.M.; McFarland, A.M.S. Using APEX to identify alternative practices for animal waste management. In Proceedings of the American Society of Agricultural Engineers Annual International Meeting, Minneapolis, MN, USA, 10-14 August 1997.

57. Moriasi, D.N.; Arnold, J.G.; VanLiew, M.W.; Bingner, R.L.; Hrmel, R.D.; Veith, T.L. Model evaluation guidelines for systematic quantification of accuracy in watershed simulations. Trans. ASABE 2007, 50, 885-900. [CrossRef]

58. Mishra, S.K.; Singh, V.P. Validity and extension of the SCS-CN method for computing infiltration and rainfall-excess rates. Hydrol. Proc. 2004, 18, 3323-3345. [CrossRef]

59. Tyagi, J.V.; Mishra, S.K.; Singh, R.; Singh, V.P. SCS-CN based time-distributed sediment yield model. J. Hydrol. 2008, 352, 388-403. [CrossRef]

(C) 2016 by the authors; licensee MDPI, Basel, Switzerland. This article is an open access article distributed under the terms and conditions of the Creative Commons Attribution (CC-BY) license (http://creativecommons.org/licenses/by/4.0/). 